\title{
Co-digestion of algae biomass for production of biogas and fertilizer: Life Cycle Cost Analysis
}

\author{
Dzintra Slisane, Francesco Romagnoli, Agris Kamenders, Ivars Veidenbergs, Dagnija \\ Blumberga \\ Riga Technical University, Institute of Energy Systems and Environment \\ Address: Azenes street 12/1, Riga, LV 1048, Latvia
}

\begin{abstract}
The purpose of this article is to determine and assess Life Cycle Costs of biogas and fertilizer produced in anaerobic digestion of biomass. General Cost Breakdown Structure for anaerobic digestion plant is described for better understanding of the system. Main cost categories discussed in this study are: Investments; Design, construction and dismantling costs; Maintenance, Operation and Transportation costs. Results showed that Design, construction and dismantling costs have the biggest share in Total Life Cycle Cost (TLCC) per cubic meter of biogas. This category also has the biggest influence on TLCC of fertilizer. Investment costs are the second most significant cost category.
\end{abstract}

Keywords: algae co-digestion, anaerobic digestion, Life Cycle Costing.

\section{INTRODUCTION}

European Commissions Renewable Energy Directive sets targets for energy sector up to 2020. The main objectives are to cover at least $20 \%$ of EU energy demand with renewable resources and to ensure that $10 \%$ of vehicle fuel used in EU also comes from renewable sources. To achieve this directive, more specified targets were set for each country. These targets are included in National action plans for energy sector. At the time when EU Renewable Energy Directive was developed, Latvia was one of the leader countries with $29.9 \%$ renewable energy share in total final energy consumption, in large part due to an extensive use of hydro energy for power and wood biomass in district heating sector. National action plan dictates that this position must be maintained and sets a target of $40 \%$ share of renewable energy sources (RES) by 2020. Year 2020 draws nearer and nearer. EU wide progress report shows that in 2010 the total share of RES had reached $12.5 \%$ in total and $4.7 \%$ in transport sector. Without serious improvements the annual growth rate of renewable energy share would stay the same and EU will fail to reach the target. The latest available progress report from Latvia is written in 2013. It describes progress Latvia has made towards the targets up to year 2012. Total renewable energy share in 2012 was $35.78 \%$. Situation in transport sector is worse. According to the Directive renewable energy share in transportation sector in each country should be at least $10 \%$ by 2020 . In 2012 RES share in Latvian transportation sector was only $3.10 \%$ [1].

Biomass has been used as energy source from ancient times, and it provides around $14 \%$ of worlds energy supply [2].Traditionally wood fuel is used for cooking and heating through direct combustion. There are other methods that can be used to convert biomass into energy. One of them is anaerobic digestion. Biogas that contains methane (biomethane) is produced as the end product of this process. [3] The first experimental biogas production plant in Latvia was designed in 1983. Technology development from then has been quite slow. In 2008 there were only 3 operating biogas production plants. Two of them used municipal waste that is collected in landfill. Several biogas production plants have been built since then. They use different feedstock, such as, manure, straw and other agricultural wastes. Collection and utilization of biogas reduces greenhouse gas emissions. Carbon dioxide, methane and other gases from landfill, which, otherwise, would be released to the atmosphere, are collected and dealt with or utilized in a useful manner. Development of biogas technologies provides opportunities to increase Latvian independence in the energy sector and strengthen the economy of rural areas. Several studies discuss the possible use of algae as a feedstock in Latvian conditions [4]. Pastare et. al. evaluates sustainability of biogas production from algae [5]. 
This paper focuses on the economical aspects of biogas production, where algae is one of the feedstocks, using Life Cycle Costing (LCC) methodology described and used by [6] and [7].

\section{METHODOLOGY}

According to European Commission, Life Cycle Costing is a tool which evaluates the costs of an asset throughout its life-cycle. LCC costing is widely used in industry, especially with products that have long life time or ones that require special treatment at endof-life stages. For example, hazardous wastes like batteries or medicine. Both the producers and consumers of the product are interested in its Life Cycle Costs. For the user price of the product is only a part of expenses related to its purchase and use. The use of some product may constitute the majority of costs related to it, for example, electricity consumption for electrical oven or coffee and filters for a coffee machine. LCC allows user to make informed and smart selection when purchasing the product. For the producers, LCC allows seeing if the production costs "pay off" and indicates opportunities to optimize costs and increase profits. [8] LCC can be based on Cost Breakdown Structure, which defines main cost categories and sub-costs from products design stage to its eventual disposal. Cost Breakdown Structure can help to justify the price charged to a client and determine which cost component has the highest impact [7].

Main focus for this LCC study is Internal Life Cycle Costs of fertilizer and biogas produced in pilot project anaerobic digestion plan, externalities are not taken into account.

\section{A. Life Cycle Cost Assessment}

Total Life Cycle Cost consists of the following components: Investments (C1), Design, construction and dismantling costs (C2), maintenance (C3), operation (C4) and transportation costs (C5). Total life Cycle costs for the plant are the sum of all these costs:

$$
L C C=C 1+C 2+C 3+C 4+C 5
$$

However the goal of our study is calculation of LCC of fertilizer from digestate obtained as byproduct from biogas production in pilot plant. Therefore it is necessary to allocate the total life cycle costs of the plant between biogas and fertilizer. Allocation of costs was performed on the basis of the benefits gained from each end product.

$$
\begin{gathered}
A_{F}=\frac{Q_{F e} \times C_{F e}}{B_{\text {Total }}} \\
A_{B}=\frac{Q_{e l} \times C_{e l}+Q_{t h} \times C_{t h}}{B_{\text {Total }}}
\end{gathered}
$$

Where:

$\mathrm{A}_{\mathrm{F}}-$ allocation to fertilizer, $\%$

$\mathrm{A}_{\mathrm{B}}$ - allocation to biogas, $\%$

$\mathrm{Q}_{\mathrm{Fe}}$ - the amount of fertiliser produced, $\mathrm{kg}$

$\mathrm{C}_{\mathrm{Fe}}$ - fertilizer price in the market, euro/kg

$\mathrm{Q}_{\mathrm{el}}$ - the amount of electricity produced, $\mathrm{kWh}$

$\mathrm{C}_{\mathrm{El}}$ - electricity price in the market, euro/kWh

$\mathrm{Q}_{\mathrm{th}}-$ amount of thermal energy, $\mathrm{kWh}$

$\mathrm{C}_{\mathrm{th}}$ - thermal energy price in the market, euro/kWh

$\mathrm{B}_{\text {tota }} \mathrm{l}$ - total income in the time period, euro

As you can see from equation (3) benefits from biogas is a sum of benefits from electricity and thermal energy, because, in this specific plant, biogas is used in CHP to produce both electrical and thermal energy. Allocated costs for fertilizer and biogas can be calculated as follows:

$$
\begin{gathered}
B G_{\text {Total }}=\text { PlantTC } \times A_{B} \\
F_{\text {Total }}=\text { PlantTC } \times A_{F}
\end{gathered}
$$

Cost Breakdown Structure in this case is selected as shown in equation (1). It consists of five already mentioned categories: Investments (C1), Design, construction and dismantling costs $(\mathrm{C} 2)$, Maintenance (C3), Operation (C4) and Transportation costs (C5). Description of each category is given in the next section.

\section{B. Cost Breakdown Structure}

Category "investment costs" include all costs related to the equipment and materials used to construct the plant. This includes the costs of anaerobic digester, equipment for algae ponds, CHP station and different supportive buildings and instruments.

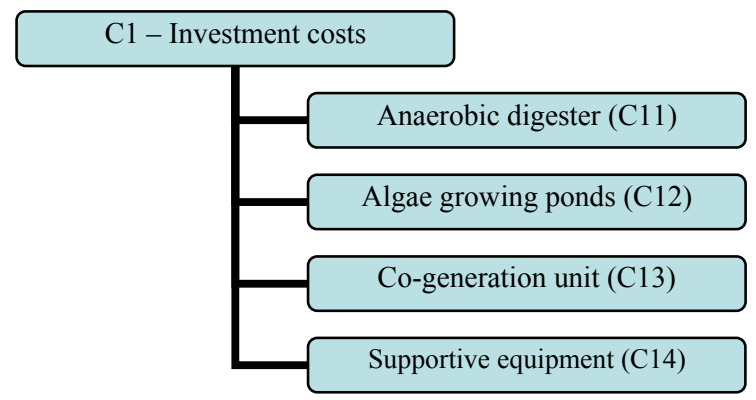

Fig.1. Cost breakdown structure of investment costs

Investment costs do not include human or energy resources necessary for the construction of biogas plant complex.

Design, construction and dismantling costs are the widest category. These costs are assumed to be mainly dependent on the capacity of the plant and are calculated as fractions of total income and investment costs. Cost breakdown structure for this category is displayed in figure below. 


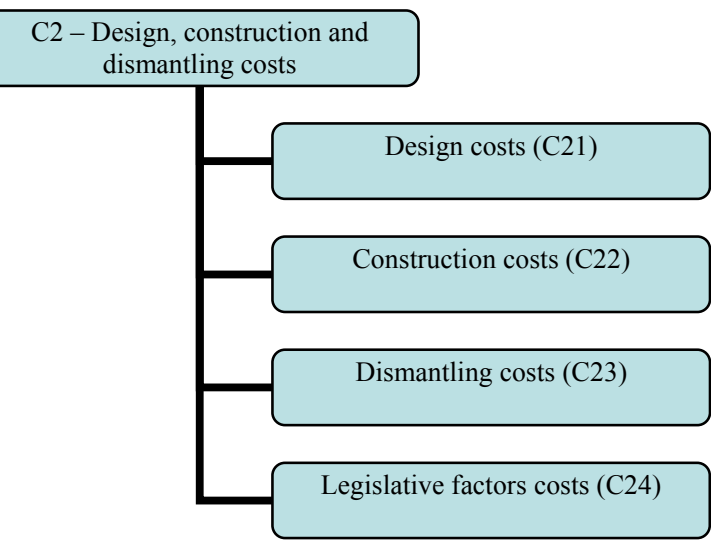

Fig.2. CBS of design construction and dismantling costs

Design costs include research and development, design of the plant and market analysis.

Maintenance cost category (See. Fig.3.) includes all repair costs as well as regular maintenance works, such as, cleaning, oiling and others.

C3- Maintenance costs

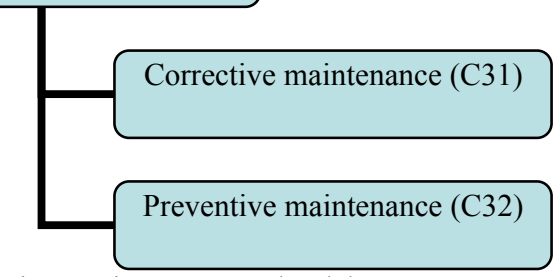

Fig.3. Maintenance cost breakdown

Next category is operational costs $(\mathrm{C} 4)$, which include all expenses related to the operation of plants equipment and feedstock storage facilities - consumed electrical and thermal energy. In this case electricity and thermal energy consumption for the operation of the plant is covered by energy produced on site; therefore operational costs are kept to minimum.

Transportation costs (C5) are all expenses related to transportation of feedstock's to the plant. Full Cost Breakdown Structure is displayed in equation (1).

\section{Description of scenarios}

LCC calculation was performed for 4 scenarios. Tree of the scenarios are for Italian conditions using different mixes of biomass. Data used in these scenarios were obtained from pilot plant described by (E. Gili) but the last one is adapted to conditions (mandatory procurement component, transport, biomass mix and others) characteristic to Latvia.

Several parameters are the same in all scenarios. Scenario 0 (base scenario): Biomass mix of Poultry manure, Citrus pulp, Olive Mill waste water (OMWW) obtained from respective industries, where they are wastes, and algae biomass cultivated on site. Transportation of biomass is assumed based on the average distance between the plant and possible suppliers. Biomass is transported using small truck (capacity 3.5 tons, with expanses 0.12 euro $/ \mathrm{km}$. The amount of biomass and total transportation distance in 1 year is displayed in Table 1 .

\begin{tabular}{|c|c|c|c|c|}
\hline Biomass & $\begin{array}{l}\text { Amount, } \\
\text { t/year }\end{array}$ & $\begin{array}{l}\text { Dry } \\
\text { matter(DM), } \\
\%\end{array}$ & $\begin{array}{l}\text { Volatile } \\
\text { solids } \\
\% \text { of } \\
\text { DM }\end{array}$ & $\begin{array}{l}\text { Total } \\
\text { transportation } \\
\text { distance, } \\
\mathrm{km} / \mathrm{year}\end{array}$ \\
\hline $\begin{array}{l}\text { Poultry } \\
\text { manure }\end{array}$ & 365 & 25 & 75 & 2520 \\
\hline OMWW & 365 & 3 & 86 & 312 \\
\hline $\begin{array}{l}\text { Citrus } \\
\text { pulp }\end{array}$ & 365 & 20 & 85 & 2340 \\
\hline Algae & 37 & 10 & 85 & - \\
\hline
\end{tabular}

Scenario 1: meet leftovers and kinder garden canteens leftovers are added to the biomass mix. Proportions of the kinds of biomass that were used in previous scenario have been changed as well, see Table 2.

TABLE 2

\begin{tabular}{|l|c|c|c|c|}
\hline Biomass & $\begin{array}{l}\text { Amount, } \\
\text { t/year }\end{array}$ & $\begin{array}{l}\text { Dry } \\
\text { matter } \\
(\mathrm{DM}), \\
\%\end{array}$ & $\begin{array}{l}\text { Volatile } \\
\text { solids \% } \\
\text { of DM }\end{array}$ & $\begin{array}{l}\text { Total } \\
\text { transportation } \\
\text { distance, } \\
\text { km/year }\end{array}$ \\
\hline $\begin{array}{l}\text { Poultry } \\
\text { manure }\end{array}$ & 17.80 & 25 & 75 & 2520 \\
\hline OMWW & 303.80 & 3 & 86 & 312 \\
\hline Citrus pulp & 365.00 & 20 & 85 & 2340 \\
\hline Algae & 49.70 & 10 & 85 & - \\
\hline $\begin{array}{l}\text { Meet } \\
\text { leftovers }\end{array}$ & 365.00 & & & 3120 \\
\hline $\begin{array}{l}\text { kindergarten } \\
\text { canteens } \\
\text { leftovers }\end{array}$ & 30.02 & & & 165 \\
\hline
\end{tabular}

Scenario 2: Scenario 2 uses the same kinds of biomass as in Scenario 1, however the proportions are changed (see Table 3.)

TABLE 3

\begin{tabular}{|l|c|}
\hline & Amount [t/year] \\
\hline Poultry manure [t*] & 280.40 \\
\hline OMWW & 365.00 \\
\hline Citrus pulp & 329.00 \\
\hline Algae & 49.70 \\
\hline Meet left. & 77.10 \\
\hline Kinder garden canteens left. & 30.02 \\
\hline
\end{tabular}

Scenario 3 (Latvian case scenario). Basic parameters such as electricity, thermal energy and fertilizer procurement price in this scenario are set 
according to real life values in Latvia. Algae and sewage sludge are used as biomass mix; the capacity of the plant is the same as in previous scenarios. Biomass mix in Scenario 3 is displayed in Table 4.

TABLE 4

\begin{tabular}{|l|c|l|c|c|}
\hline Biomass & $\begin{array}{l}\text { Amount, } \\
\text { t/year }\end{array}$ & $\begin{array}{l}\text { Dry } \\
\text { matter } \\
(\mathrm{DM}), \\
\%\end{array}$ & $\begin{array}{l}\text { Volatile } \\
\text { solids \% } \\
\text { of DM }\end{array}$ & $\begin{array}{l}\text { Total } \\
\text { transportation } \\
\text { distance, } \\
\text { km/year }\end{array}$ \\
\hline Algae & 50 & 10 & 85 & - \\
\hline $\begin{array}{l}\text { Sewage } \\
\text { sludge }\end{array}$ & 365 & 0.05 & 0.75 & 2000 \\
\hline
\end{tabular}

\section{RESULTS AND DISCUSSION}

Allocation of LCC of biogas and fertilizer separately are calculated and summarised in bar graphs.

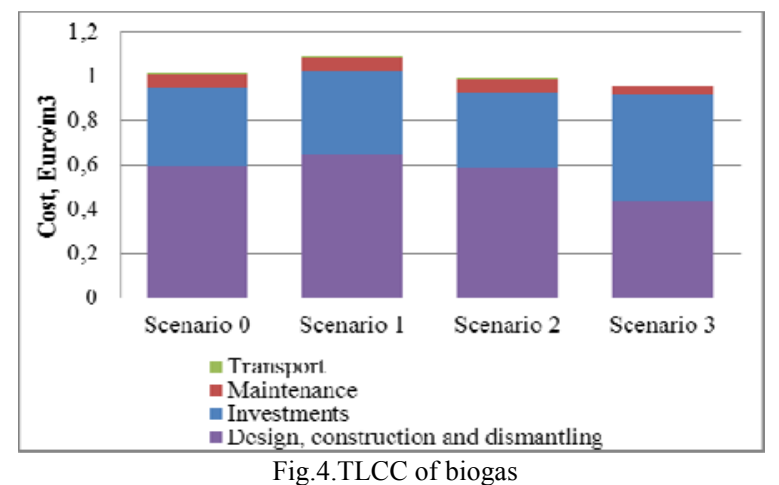

TLCC of biogas are summarised in Fig.4. As you can see calculated TLCC of biogass are around 1 euro $/ \mathrm{m}^{3}$ These results are similar to the ones obtained by Gili [6]. TLCC allocated to fertilizer are displayed in Fig.5.

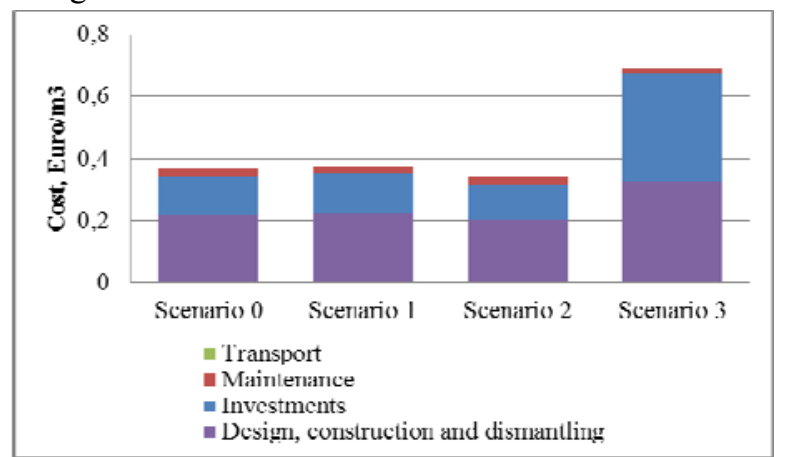

Fig.5. TLCC of fertiliser
There is significant difference between LCC of fertiliser in scenario 3 and all other scenarious. This can be partly explaind with utilization of sewadge sludge, which has considerably lower dry matter content and as a result can produce less fertilizer.

Sensitivity analysis was performed in order to determine which cost category has the highest impact on total life cycle costs. Scenario 0 (base scenario) was taken as the basis for sensitivity analysis. Figures below displays the impact on total life cycle costs per unit of fertilizer with $5 \%, 10 \%, 15 \%,-5 \%,-10 \%$ and $15 \%$ changes in certain cost categories.

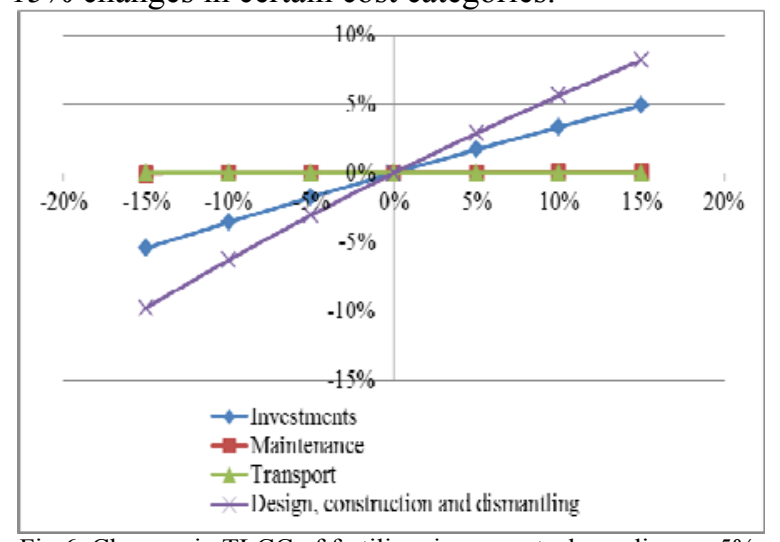

Fig.6. Changes in TLCC of fertilizer in percents depending on 5\%, $10 \%, 15 \%,-5 \%,-10 \%$ and $-15 \%$ changes different cost categories

As you can see in Figures above the most drastic change in LCC of fertilizer is in case of changes in "Design, construction and dismantling costs". This is very fortunate, because design costs will naturally decrease for other plants built by the example of this pilot plant.

This is, also one of the reasons why life cycle cost of biogas is smaller in Scenario 3. Another sensitivity test was performed in order to gain better understanding of the components and their impact on LCC of fertilizer and biogas. In this test costs in two categories were increased by $10 \%$ at the same time. Resulting changes in LCC of fertilizer in percents are displayed in Table 5. 
TABLE 5

\begin{tabular}{|l|c|c|c|c|c|c|}
\hline & Investments & Maintenance & Transportation & $\begin{array}{l}\text { Design, } \\
\text { construction and } \\
\text { dismantling }\end{array}$ & $\begin{array}{l}\text { Market price(thermal } \\
\text { energy \& electricity) }\end{array}$ & $\begin{array}{l}\text { Market price } \\
\text { (fertilizer) }\end{array}$ \\
\hline Investments & $3 \%$ & $3 \%$ & $3 \%$ & $9 \%$ & $9 \%$ & $8 \%$ \\
\hline Maintenance & $3 \%$ & $0 \%$ & $0 \%$ & $6 \%$ & $-6 \%$ & $5 \%$ \\
\hline Transportation & $3 \%$ & $0 \%$ & $0.00 \%$ & $5 \%$ & $-6 \%$ & $3 \%$ \\
\hline $\begin{array}{l}\text { Design, } \\
\text { construction and } \\
\text { dismantling }\end{array}$ & $9 \%$ & $6 \%$ & $5 \%$ & $6 \%$ & & $11 \%$ \\
\hline $\begin{array}{l}\text { Market } \\
\text { price(thermal } \\
\text { energy \& } \\
\text { electricity) }\end{array}$ & $-2 \%$ & $-6 \%$ & $-6 \%$ & & & \\
\hline $\begin{array}{l}\text { Market price } \\
\text { (fertilizer) }\end{array}$ & $8 \%$ & $5 \%$ & $3 \%$ & $11 \%$ & $6 \%$ & $0 \%$ \\
\hline
\end{tabular}

\section{CONCLUSIONS}

Life Cycle costs for digestate use as fertilizer can be divided into five main categories: Investments, Design, construction and dismantling costs, Maintenance, Operation and Transportation costs. Four biogas production scenarios were compared in this study. Design, construction and dismantling had the most impact on Life Cycle Cost of fertilizer in scenarios 0 to 2 . In the last scenario, which was assumed to operate under Latvian conditions, Investment category had the highest share of Life Cycle Costs. This was to be expected, because biogas plant in Latvia can be built following Italian example and, therefore, design costs for the plant can be reduced. Transportation share in Life Cycle Costs are very small, and this is also the narrowest category as it includes only fuel expenses for the transportation of different kinds of biomass. Sensitivity analysis also confirmed that the total Life Cycle costs are most influenced by Design, construction and dismantling cost category. There are also good opportunities to reduce costs in this category for other plants that would be constructed following this example.

\section{ACKNOWLEDGEMENT}

This work has been supported by the European Social Fund project "Involvement of Human Resources for Development of Integrated Renewable
Energy Resources Energy Production System" (project No. 2013/0014/1DP/1.1.1.2.0/13/APIA/ VIAA/026).

\section{REFERENCES}

[1] Latvijas Republika, Informatīvais ziņojums „Latvijas Republikas Otrais regulārais zinojums atbilstoši Eiropas Parlamenta un Padomes 2009. gada 23. aprīḷa Direktīvai 2009/28/EK, 2013

[2] T. V Ramachandra. Geospatial Mapping of Bioenergy Potential in Karnatak. Journal of Energy \& Environment, 6. 2007

[3] A. Wellinger. The Biogas Handbook: Science, Production and Applications. Woodhead Publishing. 2013

[4] L Pastare, F. Romagnoli, D. Lauka, I . Dzene. Sustainable Use of Macro-Algae for Biogas Production in Latvian Conditions: a Preliminary Study through an Integrated MCA and LCA Approach. In: Abstracts of 55th International Scientific Conference: Subsection: Environmental and Climate Technologies, Latvia, Rīga, 14-15 October, 2014

[5] L Pastare, F. Romagnoli, D. Lauka, I. Dzene, T. Kuzņecova. Sustainable Use of Macro-Algae for Biogas Production in Latvian Conditions: a Preliminary Study through an Integrated MCA and LCA Approach. Environmental and Climate Technologies. Vol.13, 2014, pp.44-56.

[6] E. Gili, Reuse of liquid and solid fraction of digestate as agronomic fertilizer: Life Cycle Costing and societal life cycle, BioWALK4Biofuels

[7] L. Castro-Santos, V. D.-C. Life-cycle cost analysis of floating offshore wind farms. Renewable Energy , 66, 41-48, 2014

[8] A. Ciroth, J. Franze, Life Cycle Costing in Sima Pro,GreenDelta TC Berlin, August 2009 